部を熔接で完全に修繥出来る様にするのに僅か 3 h を要する のみであつた。而もはつり作業に依るときは欠陷部の上に金 属をはつり掩つて了ふ結果大きな砂㾟をとり残す漫がある。 分ガス剂りに体り母材を傷つけることなく精密に切断し得 る点はスクラップ 作業に於ては大きな偪值を有する。熔接棈 造物は單に熔接部をガス制りすることに依て分解した板を再 生させることが出来る。

ガス刮り装置 ガス唁り用ノズルは $75^{\circ}$ 及び $90^{\circ}$ の頭 部を有する標準吹管に適合する外ガス哦り專用に蔎計された $180^{\circ}$ の真值な吹管にも使用することが出来る。ガス切断の 技術を有するものは容易に本法に熟達することが出末来る。゙ ス㓫り用ノズルの寸法は 3 種類あり、中等程度の圧力又は低 圧の何れのアセチレンガスにも使用し得る様に設計されてる る。ノズルは吹管本体に間稳を與几且裝置に対するバランス な是くするために曲げられてるる。ノズルの底部には作害中 に受ける磨耗を防ぐためにステライト合金の添板がつけてあ 万。

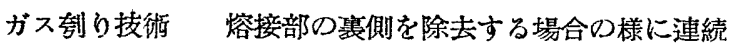
的にガス轩りする技術に就て述べると、先つ適當なノズルを 選び且酸素及びアセチレンの为希空する溝の币及び深さ を與へる樣に第 16 表に该て調整する。切断を始めるには， ズルの先端が水本と約 $20^{\circ}$ の角をなし切断すべき線の上にあ る碌に吹管を㩧る。切断を開始すべき点に予熱焰を吹かして 表面が発火点に達すると切断用酸素のレバーを漸次押下げる。 切断を徐々に進めると同時にノズル先端の角度を漸次正しい 作業位置まで淢少する。この角度は容易に識別することが出 来る。若しノズルを充分低く下げないと㷷㴖が切断部中で作 業者の方へ向いて逆流しようとするし、文吹管を余り低く下 げ過ぎると溝は浅くなり軈てなくなつて了ふ。ガス刋りを開 始する際には予熱焰の白色錐 (inner cone) の先端が品物に 丁度接する様にする。併し切断が始つてから後はノズルは切 断部表面の上方に置き、白色錐の先端は反鷹部分の $\frac{1}{4}$ 紊 in 後方にある樣にする。ノズルが淟の底部を浚ひ清める様に吹 管を持つた時に最も良い結果が得られる。

浶の形狀溝の深さは制る速さ及び切断酸素流と品物の 間の角度との函数である。深い清を切るには吹管の满に対す る角度を增し且速度をこれに應じて減少する。浅い溝を作る にはこの反対にする。巾と同じか或は少し小さい媣さの㴖を

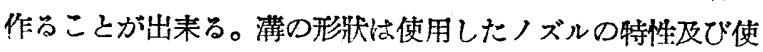
用条件に依て決る。切断用酸素の圧力が低過ぎると瑇の底部 に小波を残す。又これが高過ぎると切断は邆に消失して了ふ。 点狀ガス㻤り技術熔接の欠陷部を点狀にガス刋りする 場合には熔接部の表面にその久陷部をマークし、切断の出発 点をマークより若干一籼断した久陷部の深さによつて定め る一後方に選ぶ。支いで普通の方沠で影部を予熱してから 切断を開始するが、今度はノズルの角度を減少させず却て 漸次增して酸素の噴射を下方に向け切断が染くなる様にする。 デシーミングの場合と同㥞に僅かの経驗に体て久陷部は熔融 部分中に黑点として現はれることを容易に認めることが出来 る。焰の白色錐の先端は切断中常に板の表面より約 $\frac{1}{18}$ in 上 於ある様にすべきである。出来上つた切断部は狹いU 字
形の㴖を成し容易に熔填することが出末来る。

(中桹 金作)

\section{[64] 中子乾燥に就て}

[J. Küpper, Giesserei, 1940-8-9, Ht. 16, 頁 297] 中子砂 ○乾燥過程、溫度、堂气量の影響、溫度上昇の砂の强度に及 す試驗、通兮性、各種乾燥炻等に就て述へてるる。

(前谷 登平)

\section{[65］鋳鉄に及す Cer 混合物の影㗽}

[W. Bankloh, H. Meierling, Giesserei, 1940-9-6, Ht. 18，頁 337] Cer の鋳鉄の㙨械的性質を良好にし、脫硫、流 動性に好結果な実驗。

(晋谷 登平)

\section{［66］鋳鉄鋳物製造用の高周波電氝炉}

[W. Pfaunenschmidt, Giesserei，1940-9-6，Ht. 18，頁

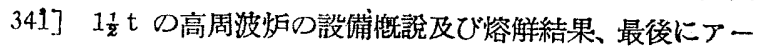
ク炻との比較。

(普谷 登平)

\section{[67］金属熔解における精鍊脫酸の 各種操業法の瞥見}

[Riedelbauch, Giesserei, 1940-9-20, Ht. 19, 頁 357] 装 大原料の基礎的条件、重金属熔佯における不良原因、銅合金 熔獬における木炭及び燐合金の影響、還元性及び酸化性添加 材、軽合金熔解時の不良原因、脫酸、精鍊に就ての一般的說 明。

(普谷 登平)

\section{[68］型及び中子の新式乾燥炬用ガス}

[W. Callenberg, Giesserei，1940-10-18，Ht. 21, 頁 397] 燃料とし、てのガスの経済、乾燥過程、各種乾燥炉。

(曋谷 登平)

\section{[69] 銓鋼用 Walkenried 砂の應用}

[F. Roll, E. Offermann, Giesserei, 1940-8-9, Ht. 16, 頁 301]

\section{[70］エレクトロン鋳物工場の排氠の問題}

[Fachausschuss "NE-Metallgusz", Giesserei, 1940-9 5, Ht. 18, 頁 347]

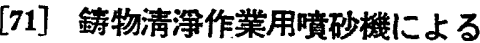 ジリコーゼ病予防に就て}

[G. Zweiling, Giesserei, 1940-9-20, Ht. 19, 頁 362]

\section{[72] 铸物作業における模型及びその} 作業経済に及す影響

[C. Wagner, Giesserei, 1940-10-4, Ht. 20, 頁 377]

[73] 錆物用鉄鉄の新價格統制

[H. Dichgars, Giesserei, 1940-10-18, Ht. 21, 頁 405] 